\title{
Effects of predation by sea ducks on clam abundance in soft-bottom intertidal habitats
}

\author{
Tyler L. Lewis ${ }^{1}$, Daniel Esler ${ }^{2, *}$, W. Sean Boyd ${ }^{3}$ \\ ${ }^{1}$ Centre for Wildlife Ecology, Simon Fraser University, 8888 University Drive, Burnaby, British Columbia V5A 1S6, Canada \\ ${ }^{2}$ Centre for Wildlife Ecology, Simon Fraser University, 5421 Robertson Road, Delta, British Columbia V4K 3N2, Canada \\ ${ }^{3}$ Canadian Wildlife Service, 5421 Robertson Road, Delta, British Columbia V4K 3N2, Canada
}

\begin{abstract}
Recent studies have documented strong, top-down predation effects of sea ducks on mussel populations in rocky intertidal communities. However, the impact of these gregarious predators in soft-bottom communities has been largely unexplored. We evaluated effects of predation by wintering surf scoters Melanitta perspicillata and white-winged scoters M. fusca on clam populations in soft-bottom intertidal habitats of the Strait of Georgia, British Columbia. Specifically, we documented spatial and temporal variation in clam density $\left(\right.$ clams $\mathrm{m}^{-2}$ ), scoter diet composition, and the consequences of scoter predation on clam abundance. Of the 3 most numerous clams, Manila clams Venerupis philippinarum and varnish clams Nuttallia obscurata were the primary prey items of both scoter species, while clams of the genus Macoma were rarely consumed by scoters. Between scoter arrival in the fall and departure in the spring, Manila clams decreased in density at most sample sites, while varnish clam densities did not change or declined slightly. Our estimates of numbers of clams consumed by scoters accounted for most of the observed declines in combined abundance of Manila and varnish clams, despite the presence of numerous other vertebrate and invertebrate species known to consume clams. For Macoma spp., we detected an over-winter increase in density, presumably due to growth of clams too small to be retained by our sieve $(<5 \mathrm{~mm})$ during fall sampling, in addition to the lack of predation pressure by scoters. These results illustrate the strong predation potential of scoters in soft-bottom intertidal habitats, as well as their potentially important role in shaping community structure.
\end{abstract}

KEY WORDS: Sea duck - Surf scoter · White-winged scoter · Soft-bottom intertidal · Prey depletion · Nuttallia obscurata $\cdot$ Venerupis philippinarum

Resale or republication not permitted without written consent of the publisher

\section{INTRODUCTION}

Numerous studies of marine communities have demonstrated effects of predators on the abundance, size distribution, and other attributes of their prey, with subsequent consequences for community structure and function (Paine 1966, 1974, Virnstein 1977, Kvitek et al. 1992, Langlois et al. 2005). In rocky intertidal habitats, which are often characterized by intense competition for space, predators may have a marked, indirect effect on the abundance of certain species by directly limiting the abundance of their strongest competitors (Paine 1966, 1974). In soft-bottom marine habitats, however, infaunal animals are not generally lim- ited by interspecific competition for space, and the abundance of infaunal animals is often directly affected by their major predators (Virnstein 1977, Peterson 1979, 1982, Wilson 1989, Estes \& Peterson 2000).

Previous studies have identified invertebrate predators, such as crabs and polychaetes, as having considerable predation effects in soft-bottom intertidal areas (Virnstein 1977, Commito 1982, Hines et al. 1990, Eggleston et al. 1992). These invertebrate predators are often numerically abundant and widespread throughout their available habitat and can thus exert strong predation pressure on infaunal animals. Vertebrate predators can also have significant predation effects in soft-bottom habitats, although they are typi- 
cally far less abundant than invertebrate predators (Virnstein 1977, Quammen 1984, Wilson 1989, Kvitek et al. 1992). Vertebrate predators tend to have higher feeding rates and increased mobility, allowing them to quickly respond to variation in prey abundance. Of the vertebrate predators, a growing body of research has identified avian species, particularly shorebirds and waders, as important predators in marine soft-bottom habitats (Szekely \& Bamberger 1992, Thrush et al. 1994, Goss-Custard et al. 1996, Zharikov \& Skilleter 2003).

In addition to shorebirds, large numbers of sea ducks (tribe: Mergini) are also found in marine soft-bottom habitats. Although their food supplies and predation effects in these habitats have gone largely unstudied (Lovvorn et al. 2003), sea ducks possess numerous attributes that suggest they could have considerable predation effects on infaunal animals (Stott \& Olson 1973). Sea ducks are large-bodied predators that often forage in large, dense flocks within intertidal and shallow subtidal zones (Goudie \& Ankney 1986) and feed almost exclusively by diving for prey, an energetically expensive method of foraging (de Leeuw 1996). In addition to the locomotory cost of diving, sea ducks generally live in cold-water environments, where they incur high energetic costs of thermoregulation (de Vries \& van Eerden 1995, de Leeuw 1996). These energetic demands require sea ducks to consume substantial amounts of food, relative to their body size, to maintain a positive energy balance (Goudie \& Ankney 1986, Guillemette et al. 1992, Guillemette 1998). The high consumption rates of sea ducks have been the focus of recent studies illustrating their ability to substantially deplete prey in wintering habitats; however, almost all of these studies have documented the depletion of mussels in rocky intertidal areas (Guillemette et al. 1996, Larsen \& Guillemette 2000, Hamilton 2000).

In the Strait of Georgia, British Columbia, surf scoters Melanitta perspicillata and white-winged scoters M. fusca are the most numerous of many sea duck species that winter in soft-bottom habitats, where they are often found in their thousands (Vermeer \& Ydenberg 1989). In these habitats, clams comprise most of the infaunal biomass and are the predominant prey item of both scoter species, as well as of a suite of other vertebrate and invertebrate predators (Vermeer 1981, Bourne 1982, 1984). Within the length range of clams commonly consumed by scoters (10 to $50 \mathrm{~mm}$; Bourne 1984), clam biomass in the Strait of Georgia does not appreciably increase during the winter residency period of scoters, due to low winter growth rates (Nosho \& Chew 1972, Williams 1980) and summerrestricted spawning events (Bourne 1982). Accordingly, the non-renewal of winter clam biomass, coupled with the predation potential and the large number of scoters, results in a situation in which significant predation effects might be expected.

We used scoter fecal samples, clam sampling, and quantification of scoter foraging behaviors to evaluate effects of predation by surf scoters and white-winged scoters on over-winter clam abundance in the Strait of Georgia. Specifically, we (1) determined composition of hard-shelled prey in scoter diets; (2) quantified changes in density of clams during the winter period of scoter residency; and (3) estimated clam consumption by scoters, contrasting consumption estimates with over-winter changes in clam abundance to evaluate the relative predation effects of scoters.

\section{MATERIALS AND METHODS}

Study area. Our study area is located in the Strait of Georgia on the east coast of Vancouver Island, British Columbia, and encompasses the marine waters of Baynes Sound $\left(49.5^{\circ} \mathrm{N}, 124.8^{\circ} \mathrm{W}\right.$; Fig. 1). Baynes Sound is a $40 \mathrm{~km}$ long coastal channel fringed by a number of small, protected bays. Large expanses of gravel and sand sediments comprise most of the intertidal habitat in Baynes Sound (Dawe et al. 1998). The area produces significant numbers of both wild and cultured bivalves and is an important wintering area for populations of waterfowl and other marine birds (Dawe et al. 1998). Waterbird surveys in Baynes Sound during the winters of 2002/2003 and 2003/2004 indicated a mean ( \pm SE) population of $6500 \pm 250$ scoters (surf scoters + whitewinged scoters) and a maximum of ca. 9000 scoters (Canadian Wildlife Service unpubl. data).

Diet estimation. To evaluate scoter diet composition, fecal samples were collected from scoters caught in Baynes Sound in December of 2001, 2002, and 2003 and in late winter of 2003 and 2004, following the capture procedures described by Lewis et al. (2005). Scoters were captured during morning hours at known foraging sites. Because scoters rarely foraged at night (Lewis et al. 2005), fecal samples originated from food consumed the morning of capture. Fecal samples were collected from clean towels lining the bottoms of portable pet carriers used to hold individual scoters. To process fecal samples, feces from each scoter were first passed through a $250 \mu \mathrm{m}$ sieve. All fragments of shell retained on the sieve were separated from non-shell objects and sorted into bivalve and non-bivalve groupings. Because shell fragments accounted for $>99 \%$ of the gross mass of all fecal samples and small rocks composed most of the non-shell objects, all non-shell objects were excluded from further analyses. Bivalve groupings were further sorted to species, while nonbivalve groupings were sorted to more coarse taxonomic classifications (e.g. crustacean, gastropod). Shell 


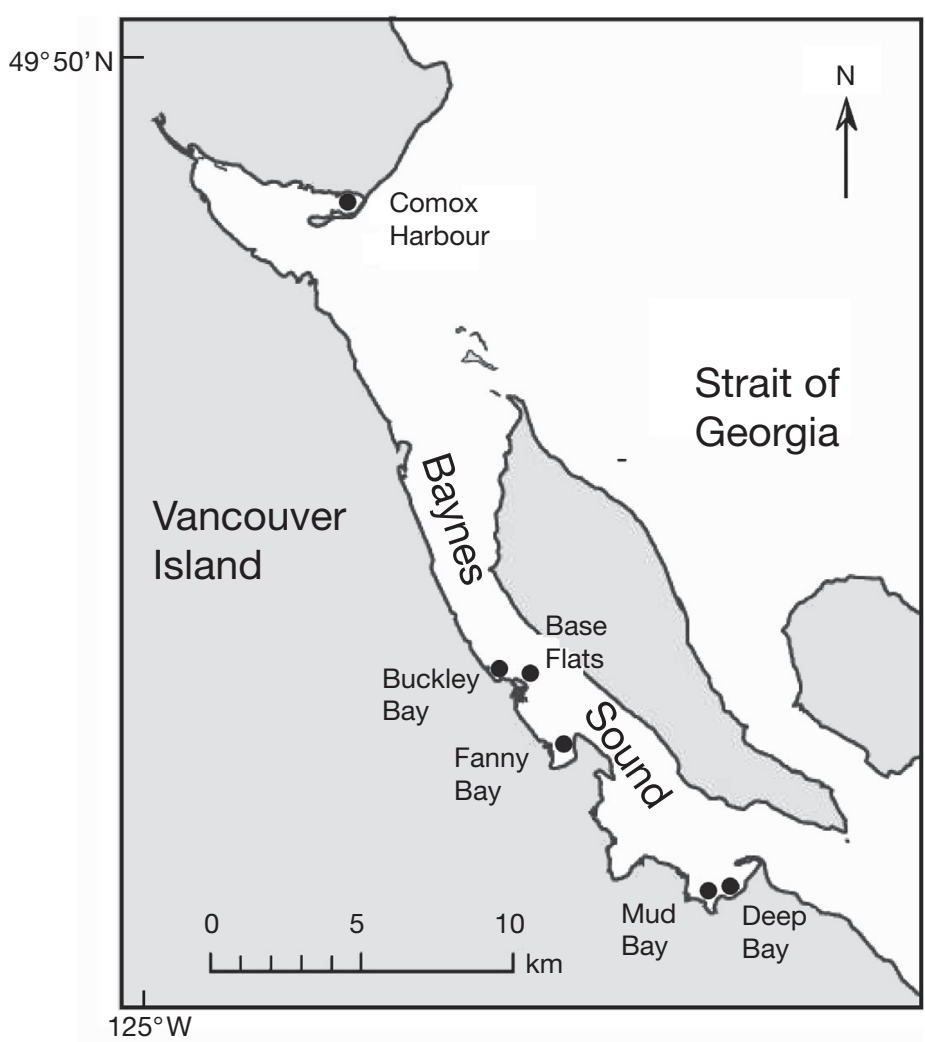

Fig. 1. Baynes Sound, extending from Comox Harbour to Deep Bay, in the Strait of Georgia, British Columbia, Canada, showing the 6 sample plots

structure, such as concentric and radial sculpture, and color of exterior and internal shell surface provided the primary diagnostic information needed to identify fecal shell fragments to species. Fecal shell fragments were compared to intact shells of known species to verify classification. For each fecal sample, sorted groupings were placed in separate aluminum petri dishes and dried at $100^{\circ} \mathrm{C}$ to constant mass.

Unidentifiable shell fragments were grouped as either unknown $(8.0 \%$ of all shell fragments) or unknown bivalve $(7.5 \%)$. These groupings were mainly composed of shell fragments that were too small for identification, but presumably reflect the species composition of the identifiable shell fragments. A separate grouping was also created to account for the close similarity in shell structure between Manila clams Venerupis philippinarum and Pacific littleneck clams Protothaca staminea. When a shell fragment could not be identified to species, but we were certain that it was either Manila or Pacific littleneck, the fragment was placed into a grouping that encompassed both species.

The percent dry mass of all fecal shell fragments was calculated for each prey type. Dry mass percentages do not account for inherent differences between the proportion of shell to soft tissue among prey types or across size classes within a prey type. Therefore, percentages are meant to provide a relative index of the importance of each hard-shelled prey item to the diet of scoters, and not an exact proportion of dietary intake.

Clam sampling. To determine intertidal clam density, 6 sample plots were established throughout Baynes Sound in the winter of 2003/2004 (Fig. 1). We sampled these plots on 2 occasions timed to coincide with scoter arrival and departure from Baynes Sound: in the fall from 23 September to 17 October 2003 and in the spring from 5 to 12 April 2004. Each sample plot measured $150 \times 150 \mathrm{~m}\left(22500 \mathrm{~m}^{2}\right)$ and was contained within an intertidal area bounded by the 1.0 and $3.5 \mathrm{~m}$ tidal heights (based on lowest low tide datum), encompassing the range of the dominant intertidal clam species in Baynes Sound (Gillespie et al. 1999, 2001). Because the elevational slope varied among sample plots, the total tidal height encompassed by each plot differed slightly by location.

Clam sampling was conducted using a 2-stage sampling methodology (Gillespie \& Kronlund 1999). The entire $150 \times 150 \mathrm{~m}$ sampling plot was divided into 300 contiguous strata $0.5 \mathrm{~m}$ wide and aligned parallel to the shoreline. These strata were then divided into 4 elevational groups, each containing 75 strata (thus each elevational group measured $150 \mathrm{~m}$ parallel to the shoreline and $37.5 \mathrm{~m}$ perpendicular to the shoreline). We then randomly selected 3 strata from each elevational group. Each selected stratum was then divided into 300 units of $0.5 \times 0.5 \mathrm{~m}$, and, of these, 6 units (hereafter termed quadrats) were selected for sampling. Thus, 72 quadrats were examined per sample plot in both fall and spring, consistent with the recommended sample rate of 30 quadrats per hectare (Gillespie \& Kronlund 1999). Quadrat locations were selected separately for fall and spring sampling, and no fall quadrat locations were re-sampled in the spring.

Each quadrat was completely excavated to a depth of $15 \mathrm{~cm}$, below which clams were considered inaccessible to foraging scoters (Lovvorn 1989, Richman \& Lovvorn 2003). All excavated substrate was passed through a $4 \mathrm{~mm}$ sieve. Sieve size was selected to retain bivalves of lengths consumed by scoters; of whole bivalves found in the esophagi of collected surf scoters and white-winged scoters, as well as similarly sized canvasbacks Aythya valisineria, spectacled eiders Somateria fischeri, and common eiders Somateria mollissima, few if any bivalves $<4 \mathrm{~mm}$ were consumed (Bourne 1984, Lovvorn 1989, Nehls \& Ketzenberg 2002, Lovvorn et al. 2003). Retained clams were identified to the species level, except for Macoma balthica, M. expansa, $M$. inquinata, M. nasuta, and $M$. obliqua, which were grouped by genus. The shell length of each clam, defined as the greatest linear distance 
between the anterior and posterior margins of the valve (Gillespie \& Kronlund 1999), was measured to the nearest $5 \mathrm{~mm}$ length class (beginning with the 5 to $9.9 \mathrm{~mm}$ size class). All clams were returned to the sample hole and re-buried.

Some of the Baynes Sound intertidal area is used by the shellfish aquaculture industry for production of commercial clams and oysters. In some locations, large nets are placed on top of portions of intertidal flats to protect commercial clam stocks from predation by sea ducks and other large predators. Foraging scoters are effectively excluded from preying on clams underneath these nets. Four of the 6 sample plots contained nets within their boundaries: Base Flats, Buckley Bay, Deep Bay, and Mud Bay (Fig. 1). The total amount of net covering each of these sample plots was measured. The Comox Harbor and Fanny Bay sample plots were free of nets. During clam sampling, all quadrats that completely overlapped nets were recorded as net, and no substrate was excavated. When quadrats partially overlapped nets, the proportion of the quadrat covered by net was estimated and only the net-free portion of the quadrat was sampled.

To evaluate variation in clam density, we fit a series of general linear models using the program SAS (SAS Institute 1999). We constructed separate a priori model sets for varnish clam Nuttallia obscurata density, Manila and Pacific littleneck density combined, and Macoma spp. density. Varnish, Manila, and Pacific littleneck clams were chosen for inclusion in model sets because they were the primary hard-shelled prey items of scoters in Baynes Sound, as determined by fecal sample analyses. A set of a priori general linear models was also constructed for the rarely consumed Macoma spp. to provide a contrast with the more commonly consumed clam species. Manila and Pacific littleneck clams were considered in combination due to the difficulty of separating the 2 species in fecal samples and their similar value to foraging scoters (Bourne 1984). This grouping, however, reflects primarily Manila clams, which numerically comprised $33.2 \%$ of all clams sampled, while Pacific littlenecks comprised only $1.6 \%$.

We used an information-theoretic approach (Burnham \& Anderson 2002) to evaluate support for each general linear model within a model set. Two explanatory variables were used to construct identical model sets for each clam species: season (fall or spring) and site (the 6 sample plots). Model sets consisted of the following: a null model with only an intercept; models with site and season singly; a model with site and season additively; and a model with site, season, and a site by season interaction. We also included 2 additional models, which were special cases of a site by season interaction, in which site differences were constrained for either the fall or spring season. The fall-constrained model considered all sites to have equal clam density in the fall, while the spring-constrained model considered all sites to have equal clam density in the spring. We refer to these models as fall-constrained and spring-constrained, respectively. Model sets for each clam species consisted of these same 7 models. We used Akaike's information criterion (AIC) to rank the fit of each model within a model set (Burnham \& Anderson 2002). $\triangle$ AIC values were used to compare the relative explanatory value of the models, with $\triangle \mathrm{AIC}$ defined as the difference between the AIC value of the best-fitting model and each respective model in the set. AIC weights $\left(\omega_{i}\right)$, which indicate the relative likelihood of a model given the data and set of models, were also calculated to provide a relative weight of evidence for each model (Burnham \& Anderson 2002). Because $\triangle \mathrm{AIC}$ and $\omega_{i}$ mainly indicate the relative importance of each model considered in our analysis, we also calculated $\mathrm{R}^{2}$ values for each model to assess their overall fit, i.e. the proportion of variation explained by each model. Furthermore, because the addition of each explanatory variable to a model decreases the AIC value unless significant variation is explained, we were able to assess the absolute importance of our explanatory variables by comparing each model to an intercept-only null model. All clam densities $\left(\right.$ clams $\left.\mathrm{m}^{-2}\right)$ are presented as means $( \pm \mathrm{SE})$.

Scoter consumption estimate. The total number of clams consumed by scoters, $C$, at each sample plot for the winter of $2003 / 2004$ was estimated by $C=T \times N \times$ $R \times S$, where $T$ is the total time available for foraging (h), $N$ is the number of scoters within the sample plot, $R$ is the dive rate (dives $\mathrm{h}^{-1}$ ), and $S$ is clam capture success (clams captured dive ${ }^{-1}$ ).

During their winter residency period, we estimated the total foraging time available to scoters as $T=$ 1616.7 h. Scoter residency period, determined from Baynes Sound waterbird surveys, included all dates from 15 October to 10 March. Spring departure coincides with the commencement of herring spawn, at which point scoters abandon their typical winter habitats and food sources within Baynes Sound. Only diurnal hours were used to calculate $T$, as scoters rarely foraged at night (Lewis et al. 2005). Civil twilight was used to define the boundary between diurnal and nocturnal periods.

The number of scoters $N$ per sample plot was estimated by counting all scoters within the boundaries of each sample plot. Offshore corners of each sample plot were marked with buoys to provide visual boundary markers for the observer. Counts were conducted approximately once per week per sample plot for the period of 1 November to 5 March. Sampling effort per sample plot was approximately evenly distributed 
throughout the core daylight hours of 08:00 to 16:00 h. During the winter months within our study site, from mid-October through late February, the lowest daily low tide occurred exclusively at night. Therefore, diurnal scoter counts were all conducted with a substantially flooded sample plot.

Clam capture success $S$ was monitored once per week at each plot from 1 November to 5 March, unless the plot was unoccupied by scoters during observation attempts. When feeding on bivalves, scoters may bring captured bivalves to the surface for manipulation and ingestion (Ydenberg 1988). As scoters surfaced following a foraging dive, the presence or absence of a clam in the bill was recorded. Only scoters for which the surfacing event was distinctly observed were included in data collection, minimizing potential bias caused by scoters that stayed longer at the surface to manipulate captured bivalves or by differences in handling times of bivalve species. Sample plots were continually scanned for surfacing scoters, with all observations restricted to the area within each sample plot. Sampling effort per sample plot was approximately evenly distributed throughout the core daylight hours of 08:00 to 16:00 h. Only observations with a minimum of 5 individuals present in the plot (mean $=29.7$ scoters; range: 5 to 120 scoters) and 50 recorded surfacing events were included in analyses. $S$ was summarized for each observation period as the proportion of successful dives.

Estimates of clam capture success are dependent on the assumption that captured bivalves are mainly consumed at the surface. Typically, diving ducks bring large bivalves to the surface and swallow small bivalves underwater (de Leeuw \& van Eerden 1992). Although some clams may have been consumed underwater by scoters, length distributions of clams sampled, as well as length of clams for which overwinter declines were detected, indicates that scoters were preying on relatively large clams; thus, our surface observations provide reliable measures of number of clams captured per dive (see 'Discussion').

The dive rate $R$ was obtained using radio telemetry. Scoters were captured and affixed with radio transmitters during December 2003, following the procedures described by Lewis et al. (2005). Radio transmitters were deployed on surf scoters (18 males, 9 females) and white-winged scoters (28 males, 20 females). In addition, scoters were captured and affixed with radio transmitters in December 2002 (surf scoters: 27 males, 15 females; white-winged scoters: 21 males, 13 females). Many of these radio-marked scoters returned to Baynes Sound for the winter of 2003/2004, allowing us to begin monitoring scoter dive rates prior to that winter's radio transmitter deployment. The radio signal disappeared when the scoter dove, and resumed when the scoter resurfaced, allowing us to document the number of dives per unit time (Wanless \& Harris 1991, Custer et al. 1996). Dive rates were monitored from 1 November to 5 March, using hand-held 4-element Yagi antennas connected to Advanced Telemetry Systems (ATS) R4000 receivers, and observations were spread approximately evenly across daylight hours for each sample site. Observation blocks of $1 \mathrm{~h}$ duration were used to determine dive rates.

To assure a spatial and temporal connection between dive-rate observations of radio-marked scoters and sample plots, locations of radio-marked scoters were determined on the same day as dive-rate observations. Point locations of radio-marked scoters and telemetry accuracy were determined following the methods described by Lewis et al. (2005). We used ArcView v.3.2 (ESRI 1999) geographic information system (GIS) software to plot scoter point locations and sample plots on a digital 1:20000 TRIM base-map of the British Columbia coast (British Columbia Ministry of Sustainable Resource Management). A buffer was created around each sample plot, radiating $750 \mathrm{~m}$ from the center point of each plot. For each dive-rate observation, inclusion in our analyses required the following temporal and spatial criteria: (1) an individual's point location was collected on the same day as that individual's dive-rate observation and (2) the point location was within a $750 \mathrm{~m}$ sample plot buffer.

Mean values for number of clams consumed by scoters $C$ (surf scoters + white-winged scoters) were calculated for each sample plot and for all sample plots combined, using data simulation (Morgan 1984). In each simulation, a value was chosen from raw data for each of the 3 variables $N, R$, and $S$. Then, 1000 simulations were run, and the mean was generated from these 1000 values. Standard errors for estimates of $C$ were calculated by propagating standard error estimates associated with $N, R$, and $S$ (Bevington 1969). All model variables used to calculate $C$ are for surf and white-winged scoters combined and do not discriminate between sex and age.

Mean values of $C$ were compared to over-winter changes in clam numbers for each sample plot and for all sample plots combined. Numerical clam changes were estimated by subtracting mean spring estimates of clam numbers from mean fall estimates. Estimates of clam numbers were based on combined density measurements for the primary clam species consumed by scoters in Baynes Sound: Manila, Pacific littleneck, and varnish clams. All estimates of clam numbers accounted for percent cover of anti-predator nets used by the shellfish aquaculture industry. Standard errors for over-winter change in clam numbers were calculated by propagating the standard errors associated with mean fall and spring clam number estimates (Bevington 1969). 
To assess the general aptitude of our scoter consumption estimates, we converted consumption estimates to energetic values and compared them with independent estimates of energy consumption. The amount of energy consumed over the winter period by scoters in our sample plots was independently estimated as follows: energy consumed $=$ (field metabolic rate/energy assimilation rate) $\times$ number of bird days (Larsen \& Guillemette 2000). Field metabolic rate (FMR) was calculated using allometric estimates for seabirds (Nagy 1987), where log FMR $\left(\mathrm{kJ} \mathrm{d}^{-1}\right)=0.904+0.704 \times \log$ body mass $(\mathrm{g})$.

We estimated scoter body mass as $1250 \mathrm{~g}$, based on body masses of surf and white-winged scoters captured in our study area during winter 2003/2004. Number of bird days was estimated from the average number of scoters in all sample plots per day multiplied by the number of days ( $147 \mathrm{~d}_{i} 15$ October to 10 March). Because no energy assimilation data are available for Manila and varnish clams, we used an energy assimilation rate of 0.75 , approximated from other studies of bivalve digestion by diving ducks (Larsen \& Guillemette 2000, Richman \& Lovvorn 2003). Similarly, because no energy density estimates are available for Manila and varnish clams, we converted our scoter consumption estimate, measured as number of clams, into energy using an allometric relationship (energy = $0.194 \times[\text { length } / 10]^{3.18}$ ), with energy measured in $\mathrm{kJ}$ and length in $\mathrm{mm}$, derived for Pacific littleneck clams (Juanes \& Hartwick 1990).

\section{RESULTS}

\section{Diet}

Bivalves accounted for $>90 \%$ of the total dry mass of shell fragments in the feces of both surf scoters Melanitta perspicillata and white-winged scoters $M$. fusca (Table 1). Of the bivalve species, Manila clams Venerupis philippinarum and varnish clams Nuttallia obscurata dominated the fecal samples for both scoter species, accounting for $>70 \%$ of the total dry mass. Varnish clams were the most prominent prey item for white-winged scoters, accounting for $46 \%$ of total dry mass of their fecal samples, while Manila clams accounted for $30 \%$. For surf scoters, Manila clams were the most prominent prey item, accounting for $52 \%$ of total dry mass of their fecal samples, while varnish clams accounted for $20 \%$. These percentages were, in fact, likely even greater since species composition within the unknown fecal category, composed of shell fragments too small for identification, was presumably similar to that of identifiable shell fragments. Also, the Manila/Pacific littleneck category was probably composed of mostly Manila shell fragments.
Table 1. Melanitta perspicillata, M. fusca. Percentage dry weight $(\mathrm{g})$ of fecal shell fragments collected from surf scoters $(\mathrm{n}=71)$ and white-winged scoters $(\mathrm{n}=162)$ in coastal British

Columbia during the winters of 2002, 2003, and 2004

\begin{tabular}{|c|c|c|}
\hline \multirow[t]{2}{*}{$\begin{array}{l}\text { Prey group } \\
\text { and species }\end{array}$} & \multicolumn{2}{|c|}{$\begin{array}{c}\% \text { weight of } \\
\text { fecal shell fragments }\end{array}$} \\
\hline & $\begin{array}{l}\text { Surf } \\
\text { scoter }\end{array}$ & $\begin{array}{l}\text { White-winged } \\
\text { scoter }\end{array}$ \\
\hline Bivalves & 90.1 & 91.1 \\
\hline Manila clam & & \\
\hline Venerupis philippinarum & 51.9 & 29.7 \\
\hline Varnish clam & & \\
\hline Nuttallia obscurata & 19.8 & 46.0 \\
\hline Pacific littleneck clam & & \\
\hline Protothaca staminea & 0.8 & 1.3 \\
\hline Manila/Pacific littleneck & 9.5 & 5.6 \\
\hline Macoma spp. & 0.4 & 0.9 \\
\hline Heart cockle & & \\
\hline Clinocardium nuttallii & 0 & 0.2 \\
\hline Bay mussel & & \\
\hline Mytilus trossulus & 0.4 & 0 \\
\hline Unknown bivalve & 7.4 & 7.5 \\
\hline Gastropods & 0 & 0.6 \\
\hline Crustaceans & 0.1 & 0.7 \\
\hline Unknown & 9.7 & 7.5 \\
\hline
\end{tabular}

\section{Clam densities}

Manila, varnish, and Macoma spp. were the most abundant clams in benthic samples, accounting for $>80 \%$ of all clams sampled. Manila clams were most common, accounting for $33.2 \%$ of all clams sampled in fall and spring, while Macoma spp. and varnish clams accounted for 25.6 and $25.2 \%$, respectively. Other clam species commonly encountered included Clinocardium nuttallii, Cryptomya californica, Saxidomus gigantea, and Mya arenaria.

The spring-constrained model best explained variation in Manila/littleneck clam densities and had an $\mathrm{R}^{2}=0.10$ (Table 2). This model indicated that Manila/littleneck clam densities differed by site in the fall, but that all sites were of a similar density in the spring. The model with site, season, and site $\times$ season also received support $(\triangle \mathrm{AIC}=1.30)$, although the AIC weight $\left(\omega_{i}=0.33\right)$ was approximately half that of the best-fitting model $\left(\omega_{i}=0.62\right)$. The top 2 models thus indicate that only models accounting for both site and seasonal differences received substantial support. Furthermore, the null model received no support $\left(\omega_{i}=\right.$ 0.00 ), indicating that the explanatory variables used in our models explained a significant amount of variance in the data. Seasonal differences in the top 2 models were due to over-winter declines in Manila/Pacific littleneck density (Fig. 2). Declines were heavily concentrated in the 25 to $45 \mathrm{~mm}$ length range; in the fall, $70 \%$ of Manila clams sampled were 25 to $45 \mathrm{~mm}$, while 
Table 2. Venerupis philippinarum, Protothaca staminea, Nuttallia obsurata and Macoma spp. General linear models evaluating variation in density (clams $\mathrm{m}^{-2}$ ) of Manila/Pacific littleneck, varnish and Macoma spp. clams during winter in coastal British Columbia, 2003/2004. For all models, the number of parameters $(k)$ includes $+1 k$ for an intercept and $+1 k$ for variance estimate. Models are listed in order of $\triangle \mathrm{AIC}$ (AIC: Akaike's information criterion)

\begin{tabular}{|c|c|c|c|c|}
\hline $\begin{array}{l}\text { Response variable/ } \\
\text { Model }\end{array}$ & $\begin{array}{l}\text { No. of } \\
\text { ameters }\end{array}$ & $\Delta \mathrm{AIC}$ & $\begin{array}{c}\text { AIC } \\
\text { weight }\left(\omega_{i}\right)\end{array}$ & $\mathrm{R}^{2}$ \\
\hline \multicolumn{5}{|l|}{ Manila/Pacific littleneck density } \\
\hline Spring-constrained & 8 & 0 & 0.62 & 0.10 \\
\hline Site + season + site $\times$ season & 13 & 1.30 & 0.33 & 0.11 \\
\hline Site + season & 8 & 5.00 & 0.05 & 0.09 \\
\hline Site & 7 & 20.10 & 0 & 0.07 \\
\hline Season & 3 & 43.05 & 0 & 0.02 \\
\hline Fall-constrained & 8 & 45.02 & 0 & 0.03 \\
\hline Null & 2 & 45.85 & 0 & 0.00 \\
\hline \multicolumn{5}{|l|}{ Varnish clam density } \\
\hline Site & 7 & 0 & 0.69 & 0.10 \\
\hline Site + season & 8 & 1.64 & 0.30 & 0.10 \\
\hline Site + season + site $\times$ season & 13 & 11.05 & 0 & 0.10 \\
\hline Spring-constrained & 8 & 37.35 & 0 & 0.05 \\
\hline Fall-constrained & 8 & 38.38 & 0 & 0.05 \\
\hline Null & 2 & 61.35 & 0 & 0.00 \\
\hline Season & 3 & 67.76 & 0 & 0.00 \\
\hline \multicolumn{5}{|l|}{ Macoma spp. density } \\
\hline Site + season & 8 & 0 & 0.82 & 0.14 \\
\hline Site + season + site $\times$ season & 13 & 3.74 & 0.13 & 0.15 \\
\hline Site & 7 & 5.26 & 0.06 & 0.13 \\
\hline Fall-constrained & 8 & 32.89 & 0 & 0.10 \\
\hline Spring-constrained & 3 & 58.25 & 0 & 0.06 \\
\hline Season & 8 & 83.90 & 0 & 0.01 \\
\hline Null & 8 & 89.00 & 0 & 0.00 \\
\hline
\end{tabular}

only $57 \%$ of Manila clams sampled in the spring were 25 to $45 \mathrm{~mm}$ (Fig. 3).

For varnish clams, the best-fitting model contained only site as an explanatory variable and had an $\mathrm{R}^{2}=$ 0.10 (Table 2). The site and season model also received support $(\triangle \mathrm{AIC}=1.64)$, but had a small AIC weight $\left(\omega_{i}=\right.$ $0.30)$ relative to the top model $\left(\omega_{i}=0.69\right)$. The explanatory variable of site was included in the top 2 models, with a combined AIC weight of 0.99, indicating that only models containing site received support. The explanatory variable of season was only marginally important, and pronounced over-winter declines were not observed for varnish clam density (Fig. 2). The null model, however, received no support $\left(\omega_{i}=0.00\right)$, indicating that, although seasonal declines were not pronounced for varnish clams, the explanatory variable of season was able to explain some of the variance in varnish clam densities. With regards to size, the majority of varnish clams (72\%) were 25 to $45 \mathrm{~mm}$ in length (Fig. 3).

For Macoma spp., the model containing site and season was the only model that received substantial sup-

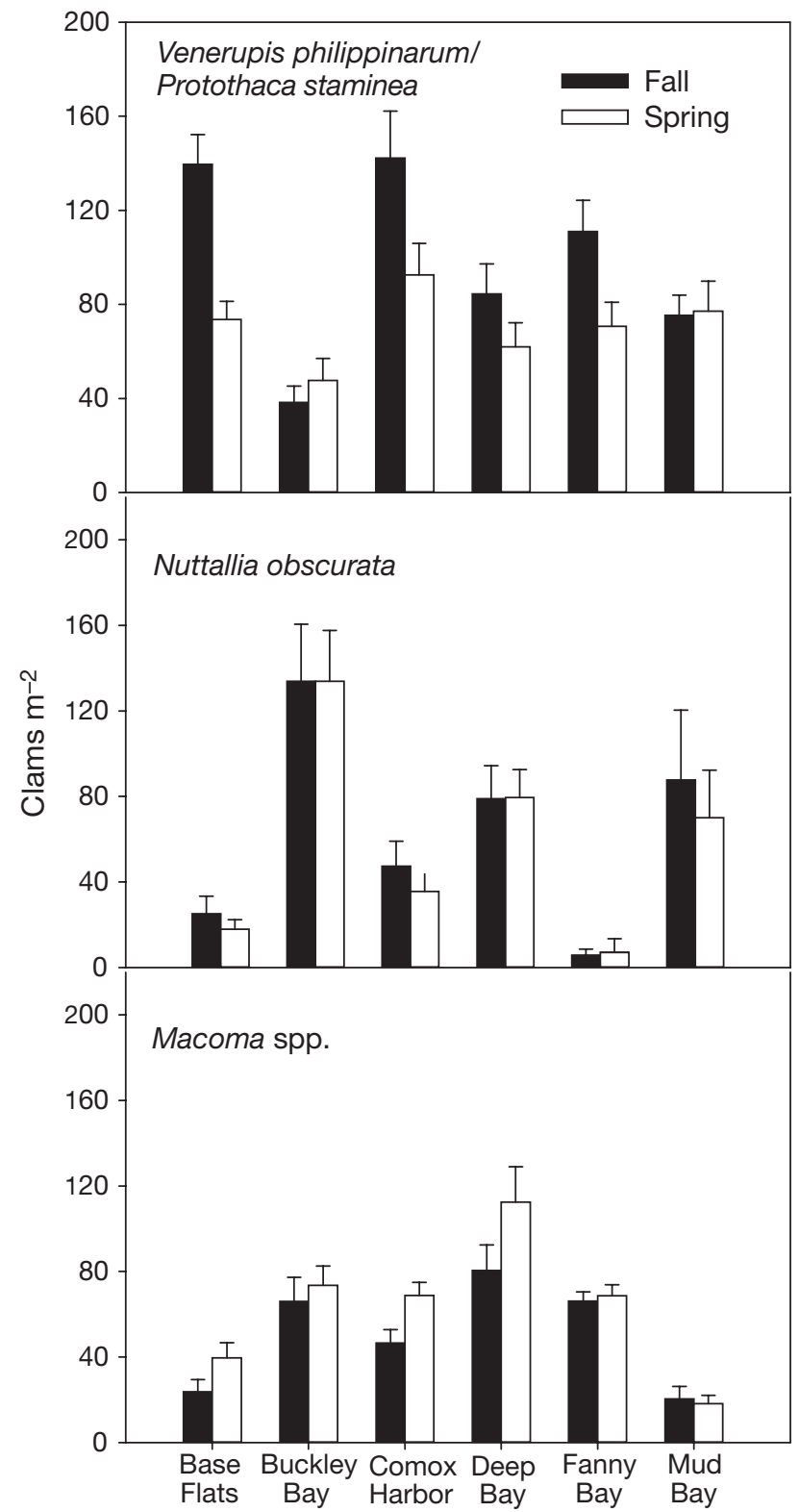

Fig. 2. Venerupis philippinarum, Protothaca staminea, Nuttallia obscurata, and Macoma spp. Density (clams $\mathrm{m}^{-2}$, mean \pm SE) of Manila/Pacific littleneck, varnish, and Macoma spp. clams at 6 sample plots in Baynes Sound, British Columbia, during fall (23 September to 17 October 2003) and spring (5 to 12 April 2004). All values are based on sampling performed with a $4 \mathrm{~mm}$ sieve

port (Table 2). The explanatory variable of season in the top model results from over-winter increases in Macoma spp. densities (Fig. 2), as opposed to density decreases observed for Manila clams. This result is consistent with our fecal sample analyses, which indicated that Macoma spp. are not consumed by scoters. Density increases are likely attributable to the overwinter growth of clams that were too small $(<5 \mathrm{~mm})$ to be retained by our sieve during fall sampling, as indi- 
cated by the increased frequency of 5 to $15 \mathrm{~mm}$ Macoma spp. in our spring samples (Fig. 3). As with Manila and varnish clams, the null model for Macoma spp. densities received no support $\left(\omega_{i}=0.00\right)$, indicating that the explanatory variables used in our models explained a significant amount of variance.

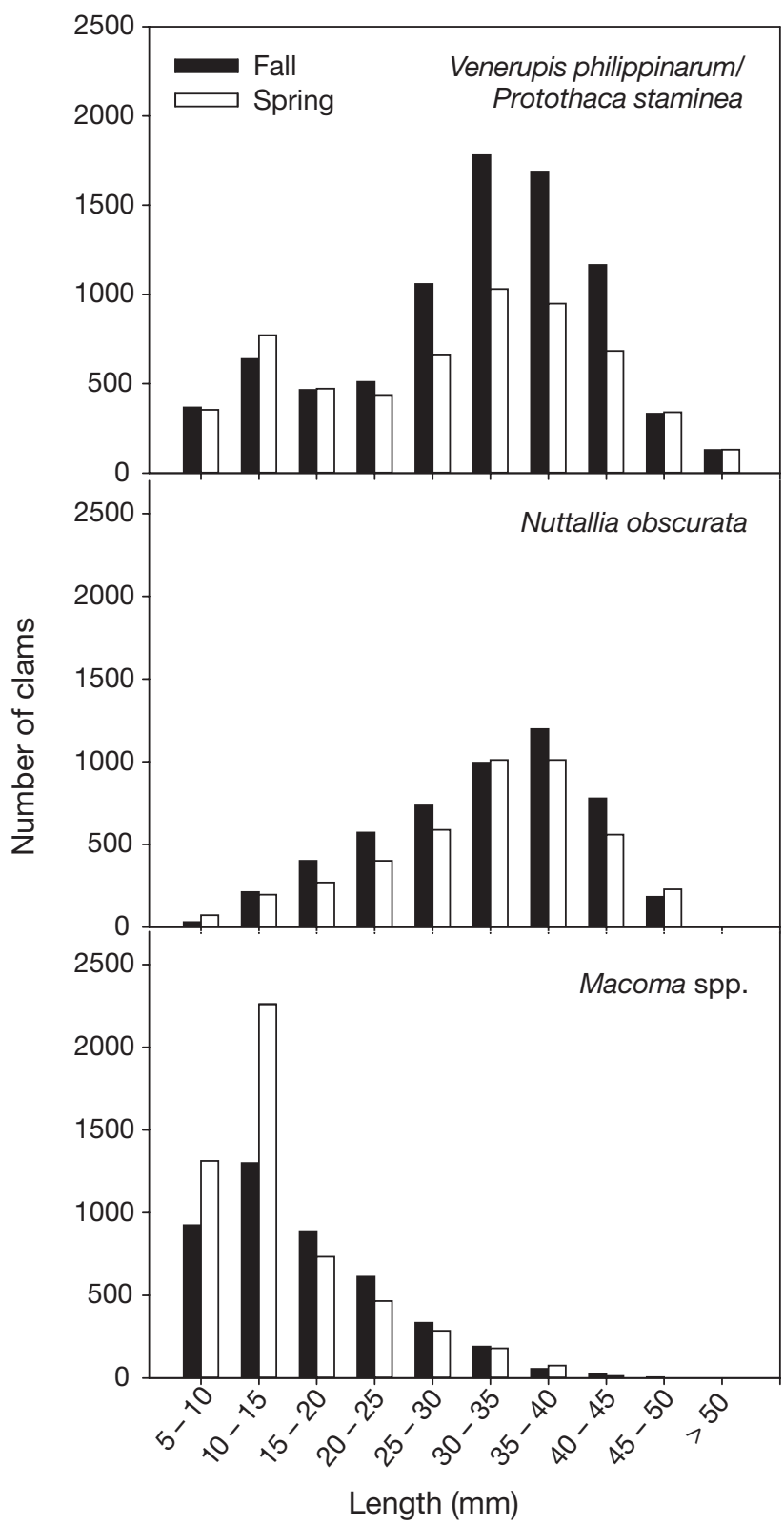

Fig. 3. Venerupis philippinarum, Protothaca staminea, Nuttallia obscurata, and Macoma spp. Length-frequency distribution, summarized into $5 \mathrm{~mm}$ length classes, of Manila/Pacific littleneck, varnish, and Macoma spp. clams in Baynes Sound, British Columbia. Number of clams are for all 6 sample plots combined during fall (23 September to 17 October 2003; $\mathrm{n}=$ 332 quadrats) and spring (5 to 12 April 2004; $\mathrm{n}=326$ quadrats). Clam numbers are based on sampling performed with a $4 \mathrm{~mm}$ sieve

\section{Scoter consumption}

For the clam species commonly consumed by scoters (Manila, Pacific littleneck, and varnish clams), the combined number of clams decreased from fall to spring at all sample plots except for Buckley Bay (Table 3). Mean estimates of number of clams consumed by scoters at each sample plot were similar in magnitude to observed over-winter changes in clam numbers (Table 3). For all sample plots combined, our mean estimate of scoter consumption accounted for approximately $90 \%$ of over-winter decreases in clam abundance. These results suggest that scoter predation was responsible for most of the observed over-winter declines in clam abundance.

The amount of energy consumed over the winter period by scoters, based on independent allometric estimates (Nagy 1987), was approximately $37 \times 10^{6} \mathrm{~kJ}$ for all 6 sample plots combined. Using a clam length of $31 \mathrm{~mm}$, which is the average length of all Manila, varnish, and Pacific littleneck clams sampled, our estimate of number of clams consumed by scoters $\left(3.67 \times 10^{6}\right.$ clams $)$ converts to approximately $26 \times$ $10^{6} \mathrm{~kJ}$. Over-winter changes to length distributions of Manila/littleneck and varnish clams (Fig. 3), however, suggest that scoters may have consumed larger clams, on average, than the average length $(31 \mathrm{~mm})$ of available clams. Using a clam length of $35 \mathrm{~mm}$, our estimate of scoter consumption converts to approximately $38 \times 10^{6} \mathrm{~kJ}$, which is similar in magnitude to the independent allometric estimate of energy consumed by scoters.

Table 3. Melanitta perspicillata, M. fusca. Over-winter clam change $\left( \pm \mathrm{SE}\right.$, no. of clams $\left.\times 10^{5}\right)$ and scoter consumption estimates $\left( \pm \mathrm{SE}\right.$, no. of clams $\left.\times 10^{5}\right)$ for all sample plots combined and for each individual sample plot during winter 2003/2004 in coastal British Columbia. Over-winter clam change is calculated from the mean fall numerical total minus mean spring numerical total for Manila, Pacific littleneck, and varnish clams combined. Scoter consumption estimates were simulated using the mean of 1000 iterations of our scoter consumption model

\begin{tabular}{|lcc|}
\hline Sample plot & $\begin{array}{c}\text { Over-winter } \\
\text { clam change } \\
\left(\text { no. of clams } \times 10^{5}\right)\end{array}$ & $\begin{array}{c}\text { Scoter consumption } \\
\text { estimate } \\
\left(\text { no. of clams } \times 10^{5}\right)\end{array}$ \\
\hline All plots combined & $-40 \pm 10$ & $36.7 \pm 1.2$ \\
Base Flats & $-9 \pm 3$ & $5.2 \pm 0.31$ \\
Buckley Bay & $+1 \pm 6$ & $3.7 \pm 0.29$ \\
Comox Harbor & $-14 \pm 8.6$ & $11 \pm 1.2$ \\
Deep Bay & $-4 \pm 7$ & $3.2 \pm 0.29$ \\
Fanny Bay & $-9 \pm 5$ & $9.1 \pm 1.2$ \\
Mud Bay & $-3 \pm 9$ & $5.0 \pm 0.5$ \\
\hline
\end{tabular}




\section{DISCUSSION}

Surf scoter Melanitta perspicillata and white-winged scoter $M$. fusca predation had significant effects on the abundance of infaunal bivalves in Baynes Sound. The scoter diet was dominated by bivalves, which accounted for nearly $90 \%$ of all identifiable fecal shell fragments. Of the bivalves, Manila Venerupis philippinarum and varnish Nuttallia obscurata clams were the primary prey of both scoter species. Our estimates of scoter consumption accounted for most of the observed declines in combined abundance of Manila, Pacific littleneck Protothaca staminea, and varnish clams, despite the presence of numerous other vertebrate and invertebrate species known to consume clams. These results illustrate the strong predation potential of scoters in soft-bottom intertidal habitats.

\section{Scoter consumption model}

Our conclusions regarding the effects of scoter predation are dependent on the accuracy of our scoter consumption model. Clam capture success, 1 of 4 variables comprising our consumption model, was estimated by measuring the proportion of scoters that surfaced from dives with a captured clam. When feeding on small bivalves (approximately $<30 \mathrm{~mm}$; J. Lovvorn pers. comm.), however, diving ducks may ingest captured bivalves underwater (de Leeuw \& van Eerden 1992). Consistent underwater ingestion of clams by scoters would cause our surface observations of clam capture success to underestimate the actual number of clams consumed. However, we believe for the following reasons that the bulk of clam consumption by scoters occurred at the water surface. First, the size distribution of clams in our study site was dominated by large clams; $61 \%$ of Manila and varnish clams sampled were $>30 \mathrm{~mm}$ ( $74 \%$ were $>25 \mathrm{~mm})$. Large bivalves require extended handling times to properly orient the clam for swallowing, as commonly witnessed for scoters (T. L. Lewis pers. obs.), and are typically handled at the surface to avoid extra costs of diving (Ydenberg 1988, de Leeuw \& van Eerden 1992). Second, declines in clam abundance were heavily concentrated in the 25 to $45 \mathrm{~mm}$ size range (Fig. 3), while smaller clams did not generally decline in abundance, suggesting that scoters focused their predation on large clams that likely required surface handling. Finally, de Leeuw \& van Eerden (1992) speculated that diving ducks optimize their intake rate per dive by consuming many small bivalves underwater before surfacing with a large bivalve to be consumed at the surface. Their conclusions were based on captive experiments in which small bivalves were abundant and all available bi- valves, both small and large, were visible to the diving duck, potentially allowing the duck to visually assess available length distributions before choosing the aforementioned dive strategy. When feeding on visually concealed prey such as clams, however, diving ducks may not be able to accurately or rapidly assess relative availabilities of small and large clams. Accordingly, to adopt such a strategy in our study site would often require scoters to bypass large clams, which are more abundant, in pursuit of small clams that occur at much lower densities, a potentially risky strategy if small clams are not found and/or a large clam is not subsequently relocated prior to dive termination.

As a whole, we recognize that our consumption model is simple, as it was intended only to provide a rough index of the magnitude of scoter consumption. Many finer details were not considered in this exercise, such as differences between scoter species and seasonal variation in foraging behaviors. Nonetheless, a consistent pattern emerges across multiple sample plots, with mean estimates of number of clams consumed by scoters closely matching in magnitude the observed declines of clam numbers. Furthermore, our estimates of scoter consumption (no. of clams), once converted into energetic values, were similar in magnitude to independent allometric estimates of energy consumed by scoters. Hence, we conclude that scoters are largely responsible for the observed over-winter declines in clam abundance.

\section{Other sources of clam mortality}

A number of potential clam predators other than scoters occur in Baynes Sound during winter, the most common of which are the red rock crab Cancer productus, the moon snail Polinices lewisii, and other diving duck species. Although these predators undoubtedly contributed to winter clam depletions, biological and numerical considerations likely restrict their overall predation effects. Invertebrate predators of clams, although often abundant, have metabolic rates and consumption requirements much lower than those of vertebrate predators such as birds. Red rock crabs can be major clam predators; their intake rates, however, are greatly reduced during winter because of low water temperatures (Walne \& Deane 1972). Moon snails are rarely observed in the mid- to high intertidal zone, where the majority of Manila and varnish clams are found, and have winter feeding rates of $<0.02$ clams d ${ }^{-1}$ in the Strait of Georgia (Peitso et al. 1994). Other diving duck species are numerous in Baynes Sound, the most common of which include Barrow's goldeneye Bucephala islandica, common goldeneye $B$. clangula, bufflehead B. albeola, harlequin ducks 
Histrionicus histrionicus, and greater scaup Aythya marila. None occur in numbers or densities nearly as high as scoters. Surf and white-winged scoters account for $>60 \%$ of all diving ducks that potentially feed on clams within Baynes Sound. The next most common diving duck, greater scaup, is known to feed on clams and other benthic invertebrates (Kessel et al. 2002), but accounts for only $12 \%$ of the potential clam-foraging ducks present in Baynes Sound. Barrow's goldeneye often has a diet composed mainly of bivalves, primarily mussels (Eadie et al. 2000), but accounts for $<1 \%$ of the potential clam-foraging ducks. The other common diving ducks typically have more diverse diets, not relying as heavily on bivalves as scoters (Gauthier 1993, Eadie et al. 1995, Robertson \& Goudie 1999).

Winter weather conditions are another potential mechanism leading to numerical declines of clams. Winter clam mortality may occur as a result of freezing, primarily when low air temperatures coincide with exposure of clam habitat at low tides. Freezing of clams is known to cause irreparable gill and tissue damage (Bower 1992). In the Strait of Georgia, Manila clams are susceptible to winter mortality by freezing during prolonged or severe cold spells (Bourne 1982). Large-scale winter die-offs are marked by the presence of abundant empty shells or recently dead clams scattered over the beach (Bower 1992). Although some clams within our study site likely died as a result of adverse weather conditions, it is not likely that large-scale die-offs were experienced during the winter of 2003/2004. At no point did we observe unusual numbers of dead clams or shells on any beaches near our sample plots, despite frequent monitoring ( $\geq 1$ visit per week) for the entire duration of winter.

\section{Manila and Pacific littleneck clams}

Manila/littleneck clam densities differed by site in the fall, prior to the arrival of large numbers of scoters in Baynes Sound. By spring, however, inter-site differences were reduced and Manila/littleneck clam densities were of a similar magnitude across sites, perhaps due to the effects of scoter predation. This large-scale homogenization could be a result of scoters depleting Manila/littleneck clams to some minimal density, and subsequently moving to a new foraging site that offered higher Manila/littleneck clam densities. Many of our sample plots, however, were $>10 \mathrm{~km}$ apart, and scoter movements of this magnitude were rare (D. Esler unpubl. radio-telemetry data). Instead, scoters used distinct over-winter foraging areas of a size that did not typically encompass multiple and/or distantly located sample plots.
The over-winter homogenization of Manila/littleneck clam densities across our 6 sample plots is more likely attributable to differential scoter numbers within our sample plots. Winter sea duck distribution and flock size is often closely related to the density of prey (Guillemette et al. 1992, 1996). Plots of higher clam density presumably attracted more scoters, and these areas experienced greater rates of predation than sites with lower clam density and fewer scoters. The persistence of this pattern for the duration of winter would eventually lead towards our observed equalization of Manila/littleneck clam densities across sites. Similar patterns have been previously observed for shorebirds in soft-bottom habitats. Densities of shorebirds are often positively correlated with density of their infaunal prey items, and sites with greater prey density and more shorebirds typically experience the largest declines in prey abundance (Goss-Custard et al. 1991, Szekely \& Bamberger 1992, Norris et al. 1998).

\section{Varnish clams}

Despite being 1 of only 2 predominant prey items found in scoter fecal samples, varnish clams did not markedly decrease in density, in contrast to Manila clams. Manila clams had overall higher densities than varnish clams, increasing their probability of detection and predation by foraging scoters, and might thus be expected to experience more pronounced over-winter declines. Differential predation by scoters, however, may not fully account for the more pronounced declines of Manila clams; the unique biology of varnish clams, along with our clam sampling protocol, may also partially explain differences between the 2 clam species.

In addition to deposit feeding, varnish clams may utilize pedal-sweep feeding (Gillespie et al. 1999), which involves collection of sub-surface organic detritus on the pedal cilia and subsequent ciliary movement of detritus to the oral region (Reid et al. 1992). This access to sub-surface food, together with their longer siphons and deeper pallial sinuses, greatly increases the burial depth capacity of varnish clams. Our clam sampling was performed to a depth of $15 \mathrm{~cm}$. This sampling regime captured all Manila clams present in a sample quadrat, as their obligatory filter feeding and short siphon length restricts their burial depth to the upper $10 \mathrm{~cm}$ (Bourne 1982). Our sampling, however, did not document all varnish clams present, as we often observed varnish clams residing deeper than $15 \mathrm{~cm}$. Although clams buried at these depths are considered unavailable to foraging scoters (Lovvorn 1989, Richman \& Lovvorn 2003), varnish clams can likely migrate vertically between upper and lower sediments. The 
burial depth of many soft-bottom bivalves varies with both season and predation risk (Zwarts 1991, Zwarts \& Wanink 1993, Peterson \& Skilleter 1994, Skilleter \& Peterson 1994). During our initial clam sampling in fall, some varnish clams may have already migrated to deeper burial depths for the duration of winter, possibly in response to predation risk of recently arriving scoters. Winter migrations to deeper sediment depths have been reported for other clam species in northern temperate locations (Zwarts \& Wanink 1993). By the time we re-sampled clam densities in April, following scoter departure from the area, some varnish clams too deep to detect in the fall $(>15 \mathrm{~cm}$ ) may have migrated to sediment depths shallow enough to be detected. This hypothesized vertical migration would partially mask our ability to detect predation of varnish clams and may partially explain the much larger over-winter declines documented for Manila clams. The mechanism driving this hypothesized migration, however, remains unknown and warrants future research into the scarcely described biology of varnish clams.

Vertical migrations of varnish clams may also partly explain our inability to detect a reduction in clam density at our Buckley Bay sample plot. For the scoterconsumed clam species of Manila, Pacific littleneck, and varnish clams combined, Buckley Bay was the only sample plot for which an over-winter density reduction was not detected, despite the confirmed predation by scoters within the sample plot. The Buckley Bay sample plot had the highest varnish clam density and lowest Manila clam density of any sample plot, with varnish clam density being approximately 3.5 times greater than Manila clam density. Accordingly, the hypothesized vertical migration of varnish clams may have had a larger effect on our ability to detect overall clam declines at our Buckley Bay sample plot relative to the other sample plots.

\section{Macoma spp. clams}

Macoma spp. clams, although comprising $25.6 \%$ of all clams sampled, were rarely consumed by scoters in Baynes Sound. We predicted that Macoma spp. densities would not decrease over the winter, due to the lack of predation pressure from scoters. As predicted, we did not detect over-winter decreases of Macoma spp. density, but rather over-winter increases. The lack of scoter predation pressure is likely attributable to the smaller size of Macoma spp., as $67 \%$ of all sampled Macoma spp. were $<15 \mathrm{~mm}$ in length, while only $16 \%$ of Manila clams and 5\% of varnish clams were $<15 \mathrm{~mm}$. Bourne (1984), in an analysis of scoter stomach contents, found that only $11 \%$ of consumed clams in Baynes Sound were $<10 \mathrm{~mm}$.
Inspection of Macoma spp. abundance by length revealed a spring increase in clam abundance for the 5 to 10 and 10 to $15 \mathrm{~mm}$ length classes, while length classes $>15 \mathrm{~mm}$ experienced little over-winter change. This suggests that Macoma spp. clams grew during the period between fall and spring clam sampling, as clams too small to be retained by our sieve in the fall $(<5 \mathrm{~mm})$ grew into sizes large enough to be detected by spring. Although clam growth is minimal during winter months in Baynes Sound for Manila clams (Bourne 1982), the growth rate of Macoma spp. clams during winter in Baynes Sound is unknown. Also, the period between our fall and spring clam sampling encompassed 6 mo, and small amounts of growth may occur during this period. Any growth over the 6 mo period would be most noticeable in the smallest size classes, because small biomass increases would cause proportionally larger changes in shell size. For Macoma spp. $>15 \mathrm{~mm}$, the absence of pronounced declines in abundance is consistent with our predicted lack of scoter predation pressure for Macoma spp. clams.

\section{Sea duck predation and community effects}

This study corroborates a growing body of literature indicating the important effects of sea duck predation on intertidal populations and communities (Guillemette et al. 1996, Hamilton 2000, Larsen \& Guillemette 2000). The large body size, high metabolic rates, and gregarious nature of sea ducks leads to high rates of predation and potentially important effects on prey abundance. To date, studies documenting the effects of sea duck predation have mainly focused on mussel prey. These studies have documented the ability of sea ducks to significantly reduce the abundance of mussels in rocky intertidal communities. The large predation effects of sea ducks on mussels may lead to subsequent changes in community structure, as mussels are dominant competitors for space, and their depredation creates open habitat for competing species (Paine 1966, 1974). Lacroix (2001) documented complete local extirpation of some mussel beds by surf scoters in coastal British Columbia, with much of the extirpation occurring high in the intertidal zone. This upper zone had been previously viewed as a predation refuge for mussels along the Pacific coast, as the classic keystone predator, the ochre sea star Pisaster ochraceus, is typically restricted to the lower intertidal zones. The predation of mussels by surf scoters may thus cause cascading community effects in the upper intertidal similar to those documented for $P$. ochraceus predation in the lower intertidal zone (Paine 1966, 1974). The presence of sea ducks as a top predator may also affect community dynamics by limiting the abundance of 
competing predators. Hamilton (2000) found that exclusion of common eiders led to an increase in the abundance of dogwhelks Nucella lapillus, as whelks were likely released from interspecific competition for available mussel prey.

The effects of sea duck predation on infaunal bivalve abundance in soft-bottom habitats had not been documented prior to the present study. By selectively preying on the most abundant infaunal animals, such as Manila and varnish clams in our study area of Baynes Sound, scoters potentially assume a particularly important role in structuring these communities. For example, Schneider (1978) documented the selective removal of numerically dominant prey by migratory shorebirds in a soft-bottom mudflat. This selective predation by shorebirds resulted in reduced variation in the relative abundance of prey by decreasing the abundance of the most common species. Within our study site during the fall, Manila, varnish, and Macoma spp. clams composed 39, 27, and 23\%, respectively, of all clams sampled. Following a winter of selective scoter predation, overall variation in the relative abundance of these 3 clam species was considerably reduced: Manila, varnish, and Macoma spp. clams composed 28,23 , and $29 \%$, respectively, of all clams sampled in the spring. In addition to changes in relative abundance, scoter predation may alter community structure via competition-dependent pathways. For example, predation by scoters on the abundant Manila and varnish clams may promote species persistence and community diversity by creating space for competitively subordinate species. Soft-bottom communities, however, are typically defined by weaker spatial competition than that found in rocky intertidal communities, and predation is believed to be of more importance than competition in limiting infaunal invertebrate densities (Virnstein 1977, Peterson 1982, 1991). Scoter predation may therefore provide a major numerical control of the abundant varnish and Manila clams, while having a less pronounced cascading community impact than might be expected in rocky intertidal habitats characterized by stronger spatial competition (Kvitek et al. 1992).

In conclusion, our study has shown the ability of scoters to deplete their winter food sources and assume a significant predation role in soft-bottom intertidal areas. Despite the presence of many other predator species, scoter predation on clams appeared responsible for most of the over-winter declines in clam abundance. Future research is needed to determine if the seasonal predation impacts we observed affect longterm clam densities and community structure. Recruitment and growth of most Baynes Sound clam species occurs during the summer months, and this repopulation may be more than adequate to renew clam numbers following winter decreases. Nonetheless, the strong predation potential of scoters requires the presence of wintering areas with robust bivalve populations. Previous studies in the Dutch Wadden Sea have linked significant over-winter mortality of common eiders to shortages of bivalve food supplies (Camphuysen et al. 2002). In areas used by wintering scoters, availability of bivalve stocks should be considered when reviewing activities, such as foreshore development or commercial bivalve harvesting, which may significantly reduce bivalve numbers.

Acknowledgements. Funding and support for this project were provided by the Canadian Wildlife Service of Environment Canada and National Science and Engineering Council (NSERC) Strategic Grant STPGP246079-01. We also thank the Centre for Wildlife Ecology, Simon Fraser University, for providing scientific and logistic support. M. McAdie and D. Mulcahy performed the radio-implant surgeries. J. Lovvorn, D. Green, C. Peterson, and R. Ydenberg provided valuable feedback on the manuscript and B. Gurd provided statistical advice. The following people helped capture scoters and provided field assistance: E. Anderson, B. Bartzen, T. Bowman, S. Coulter, R. Dickson, G. Grigg, S. Iverson, M. Kirk, D. Lacroix, R. Lis, A. McLean, E. Sellentin, and S. Wallace. We also thank all private landowners within Baynes Sound who granted us access to their property.

\section{LITERATURE CITED}

Bevington PR (1969) Data reduction and error analysis for the physical sciences. McGraw-Hill, San Francisco, CA

Bourne N (1982) Distribution, reproduction, and growth of Manila clam, Tapes philippinarum (Adams and Reeves), in British Columbia. J Shellfish Res 2:47-54

Bourne N (1984) Clam predation by scoter ducks in the Strait of Georgia, British Columbia, Canada. Can Tech Rep Fish Aquat Sci 1331

Bower SM (1992) Winter mortalities and histopathology in Japanese littlenecks [Tapes philippinarum (A. Adams and Reeve, 1850)] in British Columbia due to freezing temperatures. J Shellfish Res 11:255-263

Burnham KP, Anderson DR (2002) Model selection and multi-model inference: a practical information-theoretic approach, 2nd edn. Springer-Verlag, New York

Camphuysen CJ, Berrevoets CM, Cremers HJWM, Dekinga A and 8 others (2002) Mass mortality of common eiders (Somateria mollissima) in the Dutch Wadden Sea, winter 1999/2000: starvation in a commercially exploited wetland of international importance. Biol Conserv 106:303-317

Commito JA (1982) Importance of predation by infaunal polychaetes in controlling the structure of a soft-bottom community in Maine, USA. Mar Biol 68:77-81

Custer CM, Custer TW, Sparks DW (1996) Radio telemetry documents 24-hour feeding activity of wintering lesser scaup. Wilson Bull 108:556-566

Dawe NK, Buechert R, Trethewey DEC (1998) Bird use of Baynes Sound-Comox Harbour, Vancouver Island, British Columbia, 1980-1981. Technical Report Series No. 286, Canadian Wildlife Service, Pacific and Yukon Region, Delta

de Leeuw JJ (1996) Diving costs as a component of daily energy budgets of aquatic birds and mammals: generaliz- 
ing the inclusion of dive-recovery costs demonstrated in tufted ducks. Can J Zool 74:2131-2142

de Leeuw JJ, van Eerden MR (1992) Size selection in diving tufted ducks Aythya fuligula explained by differential handling time of small and large mussels Dreissena polymopha. Ardea 80:353-362

de Vries J, van Eerden MR (1995) Thermal conductance in aquatic birds in relation to the degree of water contact, body mass, and body fat: energetic implications of living in a strong cooling environment. Physiol Zool 68:1143-1163

Eadie JM, Mallory ML, Lumsden HG (1995) Common goldeneye (Bucephala clangula). In: Poole A, Gill F (eds) The birds of North America (No. 170). Academy of Natural Sciences, Philadelphia and American Ornithologists' Union, Washington, DC

Eadie JM, Savard JP, Mallory ML (2000) Barrow's goldeneye (Bucephala islandica). In: Poole A, Gill F (eds) The birds of North America (No. 548). Academy of Natural Sciences, Philadelphia and American Ornithologists' Union, Washington, DC

Eggleston DB, Lipcius RN, Hines AH (1992) Density-dependent predation by blue crabs upon infaunal clam species with contrasting distribution and abundance patterns. Mar Ecol Prog Ser 85:55-68

ESRI (Environmental Systems Research Institute) (1999) Getting to know ArcView GIS. ESRI Press, Redlands, CA

Estes JA, Peterson CH (2000) Marine ecological research in seashore and seafloor systems: accomplishments and future directions. Mar Ecol Prog Ser 195:281-289

Gauthier G (1993) Bufflehead (Bucephala albeola). In: Poole A, Gill F (eds) The birds of North America (No. 67). Academy of Natural Sciences, Philadelphia and American Ornithologists' Union, Washington, DC

Gillespie GE, Kronlund AR (1999) A manual for intertidal clam surveys. Can Manuscr Rep Fish Aquat Sci 2270

Gillespie GE, Parker M, Merilees W (1999) Distribution, abundance, biology and fisheries potential of the exotic varnish clam (Nuttallia obscurata) in British Columbia. Canadian Stock Assessment Secretariat Research Document 99/193, Fisheries and Oceans Canada, Nanaimo

Gillespie GE, Rusch B, Gormican SJ, Marshall R, Munroe D (2001) Further investigations of the fisheries potential of the exotic varnish clam (Nuttallia obscurata) in British Columbia. Canadian Stock Assessment Secretariat Research Document 2001/143, Fisheries and Oceans Canada, Nanaimo

Goss-Custard JD, Warwick RM, Kirby R, McGrorty S and 5 others (1991) Towards predicting wading bird densities from predicted prey densities in a post-barrage Severn estuary. J Appl Ecol 28:1004-1026

Goss-Custard JD, McGrorty S, Dit Durell SEALV (1996) The effect of oystercatchers (Haematopus ostralegus) on shellfish populations. Ardea 84A:453-467

Goudie RI, Ankney CD (1986) Body size, activity budgets, and diets of sea ducks wintering in Newfoundland. Ecology $67: 1475-1482$

Guillemette M (1998) The effect of time and digestion constraints in common eiders while feeding and diving over blue mussel beds. Funct Ecol 12:123-131

Guillemette M, Ydenberg RC, Himmelman JH (1992) The role of energy intake rate in prey and habitat selection of common eiders Somateria mollissima in winter: a risksensitive interpretation. J Anim Ecol 61:599-610

Guillemette M, Reed A, Himmelman JH (1996) Availability and consumption of food by common eiders wintering in the Gulf of St. Lawrence: evidence of prey depletion. Can J Zool 74:32-38
Hamilton DJ (2000) Direct and indirect effects of predation by common eiders and abiotic disturbance in an intertidal community. Ecol Monogr 75:21-43

Hines AH, Haddon AM, Wiechert LA (1990) Guild structure and foraging impact of blue crabs and epibenthic fish in a subestuary of Chesapeake Bay. Mar Ecol Prog Ser 67: 105-126

Juanes F, Hartwick EB (1990) Prey size selection in Dungeness crabs: the effect of claw damage. Ecology 71:744-758

Kessel B, Rocque DA, Barclay JS (2002) Greater scaup (Aythya marila). In: Poole A, Gill F (eds) The birds of North America (No. 650). Academy of Natural Sciences, Philadelphia and American Ornithologists' Union, Washington, DC

Kvitek RG, Oliver JS, DeGange AR, Anderson BS (1992) Changes in Alaskan soft-bottom prey communities along a gradient in sea otter predation. Ecology 73:413-428

Lacroix DL (2001) Foraging impacts and patterns of wintering surf scoters feeding on bay mussels in coastal Strait of Georgia, British Columbia. MSc dissertation, Simon Fraser University, Burnaby

Langlois TJ, Anderson MJ, Babcock RC (2005) Reef-associated predators influence adjacent soft-sediment communities. Ecology 86:1508-1519

Larsen JK, Guillemette M (2000) Influence of annual variation in food supply on abundance of wintering common eiders Somateria mollissima. Mar Ecol Prog Ser 201:301-309

Lewis TL, Esler D, Boyd WS, Zydelis R (2005) The nocturnal foraging behaviors of wintering surf scoters and whitewinged scoters. Condor 107:636-646

Lovvorn JR (1989) Distributional responses of canvasback ducks to weather and habitat change. J Appl Ecol 26: $113-130$

Lovvorn JR, Richman SE, Grebmeier JM, Cooper LW (2003) Diet and body condition of spectacled eiders wintering in pack ice of the Bering Sea. Polar Biol 26:259-267

Morgan JT (1984) Elements of simulation. Chapman Hall Press, London

Nagy KA (1987) Field metabolic rate and food requirement scaling in mammals and birds. Ecol Monogr 57:11-128

Nehls G, Ketzenberg C (2002) Do common eiders Somateria mollissima exhaust their food resources? A study on natural mussel Mytilus edulis beds in the Wadden Sea. Dan Rev Game Biol 16:47-61

Norris K, Bannister RCA, Walker PW (1998) Changes in the number of oystercatchers Haematopus ostralegus wintering in the Burry Inlet in relation to the biomass of cockles Cerastoderma edule and its commercial exploitation. J Appl Ecol 35:75-85

Nosho TY, Chew KK (1972) The setting and growth of the Manila clam, Venerupis japonica (Deshayes), in Hood Canal, Washington. Proc Natl Shellfish Assoc 62:50-58

Paine RT (1966) Food web complexity and species diversity. Am Nat 100:65-75

Paine RT (1974) Experimental studies on the relationship between a dominant predator and its principal competitor. Oecologia 15:93-120

Peitso E, Hui E, Hartwick B, Bourne N (1994) Predation by the naticid gastropod Polinices lewisii (Gould) on littleneck clams Protothaca staminea (Conrad) in British Columbia. Can J Zool 72:319-325

Peterson CH (1979) Predation, competitive exclusion, and diversity in the soft-sediment benthic communities of estuaries and lagoons. In: Livingston RJ (ed) Ecological processes in coastal and marine systems. Plenum Press, New York, p 233-264

Peterson CH (1982) The importance of predation and intraand interspecific competition in the population biology of 
two infaunal suspension-feeding bivalves, Protothaca staminea and Chione undatella. Ecol Monogr 52:437-475

Peterson CH (1991) Intertidal zonation of marine invertebrates in sand and mud. Am Sci 79:236-249

Peterson CH, Skilleter GA (1994) Control of foraging behavior of individuals within an ecosystem context: the clam Macoma balthica, flow environment, and siphon-cropping fishes. Oecologia 100:256-267

Quammen ML (1984) Predation by shorebirds, fish, and crabs on invertebrates in intertidal mudflats: an experimental test. Ecology 65:529-537

Reid RGB, McMahon RF, Foighil DO, Finnigan R (1992) Anterior inhalant currents and pedal feeding in bivalves. Veliger 35:93-104

Richman SE, Lovvorn JR (2003) Effects of clam species dominance on nutrient and energy acquisition by spectacled eiders in the Bering Sea. Mar Ecol Prog Ser 261:283-297

Robertson GJ, Goudie RI (1999) Harlequin duck (Histrionicus histrionicus). In: Poole A, Gill F (eds) The birds of North America (No. 466). Academy of Natural Sciences, Philadelphia and American Ornithologists' Union, Washington, DC

SAS Institute (1999) SAS/STAT software, Version 8.0. SAS Institute, Cary, NC

Schneider D (1978) Equalisation of prey numbers by migratory shorebirds. Nature 271:353-354

Skilleter GA, Peterson CH (1994) Control of foraging behavior of individuals within an ecosystem context: the clam Macoma balthica and interactions between competition and siphon cropping. Oecologia 100:268-278

Stott RS, Olson DP (1973) Food-habitat relationship of sea ducks on the New Hampshire coastline. Ecology 54: 996-1007

Szekely T, Bamberger Z (1992) Predation of waders (Charadrii) on prey populations: an exclosure experiment. J Anim Ecol 61:447-456

Thrush SF, Pridmore RD, Hewitt JE, Cummings VJ (1994) The importance of predators on a sandflat: interplay between

Editorial responsibility: Charles Peterson (Contributing Editor), Morehead City, North Carolina, USA seasonal changes in prey densities and predator effects. Mar Ecol Prog Ser 107:211-222

Vermeer K (1981) Food and populations of surf scoters in British Columbia. Wildfowl 32:107-116

Vermeer K, Ydenberg RC (1989) Feeding ecology of marine birds in the Strait of Georgia. In: Vermeer K, Butler RW (eds) The ecology and status of marine and shoreline birds in the Strait of Georgia, British Columbia. Spec Publ, Canadian Wildlife Service, Ottawa, p 62-73

Virnstein RW (1977) The importance of predation by crabs and fishes on benthic infauna in Chesapeake Bay. Ecology 58:1199-1217

Walne PR, Dean GJ (1972) Experiments on predation by the shore crab, Carcinus maenas, on Mytilus and Mercenaria. J Cons Int Explor Mer 34:190-199

Wanless S, Harris MP (1991) Diving patterns of full-grown and juvenile rock shags. Condor 93:44-48

Williams JG (1980) Growth and survival in newly settled spat of the Manila clam, Tapes japonica. Fish Bull 77:891-900

Wilson WH (1989) Predation and the mediation of intraspecific competition in an infaunal community in the Bay of Fundy. J Exp Mar Biol Ecol 132:221-245

Ydenberg RC (1988) Foraging by diving birds. In: Ouellet H (ed) Acta XIX Congressus Internationalis Ornithologici, Ottawa, Ontario (1986). National Museum of Natural Science, Ottawa, p 1832-1842

Zharikov Y, Skilleter GA (2003) Depletion of benthic invertebrates by bar-tailed godwits Limosa lapponica in a subtropical estuary. Mar Ecol Prog Ser 254:151-162

Zwarts L (1991) Seasonal variation in body weight of the bivalves Macoma balthica, Scrobicularia plana, Mya arenaria, and Cerastoderma edule in the Dutch Wadden Sea. Neth J Sea Res 28:231-245

Zwarts L, Wanink JH (1993) How the food supply harvestable by waders in the Wadden Sea depends on the variation in energy density, body weight, biomass, burying depth and behaviour of tidal flat invertebrates. Neth J Sea Res 31: 441-476

Submitted: August 3, 2005; Accepted: May 17, 2006 Proofs received from author(s): November 27, 2006 